\title{
KADAR TUMOR NECROSIS FACTOR - $\alpha$ PADA SERUM PENDERITA MALARIA DENGAN GEJALA DEMAM
}

\author{
Monica Thiosanto \\ Janno Bernadus \\ Josef S. B. Tuda

\begin{abstract}
Bagian Parasitologi Fakultas Kedokteran Universitas Sam Ratulangi Manado
Email: monicathiosanto@yahoo.co.id
\end{abstract}

\begin{abstract}
Malaria is classified as one of the infectious diseases that is very dangerous and can cause death. It is caused by parasites that live and thrive in human red blood cells. The disease is not just a problem in developing countries but also in developed countries. As an infectious disease, one of malaria clinical symptoms is fever. Theoretically, it is stated that TNF- $\alpha$ belongs to the cytokines that can cause fever. This was a descriptive study. The body temperatures of patients with malaria fever were measured and the levels of serum TNF- $\alpha$ were examined by using the ELISA method. There were 40 samples obtained by using simple random sampling. The results showed that moderate level of TNF- $\alpha(100-500 \mathrm{pg} / \mathrm{ml})$ was found in 36 samples (90\%); low level of TNF- $\alpha(<100 \mathrm{pg} / \mathrm{ml})$ in 4 samples $(10 \%)$; meanwhile high level of TNF- $\alpha$ was not found ( $0 \%$ ). The data showed that although in most samples the increased body temperatures were associated by the increased TNF- $\alpha$ levels, this condition was not found in all samples Conclusion: In general, the levels of TNF- $\alpha$ increased in patients with malaria fever.
\end{abstract}

Keywords: TNF- $\alpha$, malaria, fever

\begin{abstract}
Abstrak: Malaria tergolong sebagai salah satu penyakit infeksi yang sangat berbahaya dan dapat menyebabkan kematian. Penyakit ini bukan hanya menjadi masalah di negara berkembang, namun juga di negara-negara maju. Malaria disebabkan oleh parasit yang hidup dan berkembang dalam sel darah merah manusia. Sebagai penyakit infeksi, malaria memiliki gejala-gejala klinis, salah satunya ialah demam. Dikatakan bahwa TNF- $\alpha$ merupakan sejenis sitokin yang menyebabkan terjadinya demam. Penelitian ini bersifat deskriptif dengan sampel sejumlah 40 penderita malaria yang diambil secara simple random sampling. Dalam penelitian ini dilakukan pengukuran suhu tubuh penderita malaria yang disertai demam dan kadar serum TNF- $\alpha$ dengan menggunakan metode ELISA. Hasil penelitian memperlihatkan bahwa kadar TNF- $\alpha$ sedang (100-500 pg/ml) ditemukan pada 36 sampel (90\%), kadar rendah $(<100 \mathrm{pg} / \mathrm{ml})$ pada 4 sampel (10\%), sedangkan kadar tinggi tidak ditemukan (0\%). Data yag diperoleh memperlihatkan bahwa walaupun pada sebagian besar kasus peningkatan suhu tubuh disertai dengan peningkatan kadar serum TNF- $\alpha$, namun kondisi ini tidak berlaku bagi seluruh sampel. Simpulan: Kadar TNF- $\alpha$ umumnya meningkat pada penderita malaria yang mengalami demam.
\end{abstract}

Kata kunci: TNF- $\alpha$, malaria, demam

Malaria adalah penyakit infeksi parasit plasmodium yang menyerang eritrosit dan ditandai dengan ditemukannya bentuk aseksual dalam darah. ${ }^{1}$ Beberapa jenis plasmodia yang menginfeksi manusia ialah
$P$. vivax, $P$. falciparum, $P$. malariae, dan $P$. ovale. ${ }^{1-4}$ Infeksi malaria dapat berlangsung akut maupun kronik dengan gejala berupa demam, menggigil, anemia, dan splenomegali. ${ }^{1}$ Estimasi kejadian malaria 
dari World Health Organization (WHO) menunjukkan bahwa pada tahun 2010, dari 219 juta kasus malaria, 660.000 ribu di antaranya meninggal dunia. Sekitar 91\% kematian pada tahun 2010 terjadi di daerah Afrika, diikuti oleh Asia Tenggara termasuk Indonesia (6\%). ${ }^{5}$ Pada tahun 2011, kasus malaria di Indonesia dilaporkan mencapai 1.411.156 dengan jumlah kematian mencapai 1.151 jiwa. $^{6}$

Infeksi parasit malaria dimulai saat nyamuk Anopheles betina menggigit manusia. Nyamuk akan melepaskan sporozoit ke dalam pembuluh darah yang akan menuju ke hati untuk memulai perkembangan aseksual. Setelah sel-sel parenkim hati terinfeksi, terbentuk skizon hati yang bila pecah akan mengeluarkan banyak merozoit ke sirkulasi darah. Setelah berada dalam sirkulasi darah, merozoit akan menyerang eritrosit dan masuk melalui reseptor permukaan eritrosit. Di dalam eritrosit, parasit berubah menjadi skizon, dan bila pecah akan mengeluarkan 6-36 merozoit yang siap menginfeksi eritrosit lain. ${ }^{1,7,8}$

Manifestasi klinik malaria tergantung pada imunitas penderita dan tingginya transmisi infeksi malaria. Berat/ringannya infeksi dipengaruhi oleh antara lain jenis plasmodium, daerah asal infeksi, dan usia. Gambaran karakteristik malaria ialah demam periodik, anemia, dan splenomegali. Masa inkubasi bervariasi pada masing-masing jenis plasmodium. Keluhan prodormal yang dapat terjadi sebelum terjadinya demam, berupa kelesuan, malaise, sakit kepala, sakit belakang, rasa dingin di punggung, nyeri sendi dan tulang, demam ringan, anoreksia, perut berasa tak enak, diare ringan, dan kadang-kadang rasa dingin. Gejala klasik yaitu terjadinya "Trias Malaria” secara berurutan, yaitu periode dingin, periode panas, dan periode berkeringat. ${ }^{1,3,4,9}$

Demam ialah terjadinya peningkatan suhu tubuh di atas batas normal, dalam hal ini di atas $37,3^{\circ} \mathrm{C}$ jika diukur pada aksila. ${ }^{10}$ Pada malaria, eritrosit terinfeksi parasit yang pecah sewaktu proses skizogoni mengeluarkan toksin seperti glycosyl- phosphatidylinositols (GPI), hemozosin, atau mungkin antigen parasit lain. Toksin tersebut akan merangsang makrofag dan limfosit $\mathrm{T}$ helper menghasilkan berbagai sitokin. Sitokin yang berperan penting pada patogenesis malaria meliputi TNF- $\alpha$, limfotoksin, IL-1, IL-6, interferon (IFN- $\gamma$ ), dan IL-10. ${ }^{9}$

Sitokin-sitokin yang dihasilkan, dalam hal ini TNF- $\alpha$, bekerja di hipotalamus dengan bantuan enzim siklooksigenase membentuk prostaglandin yang selanjutnya meningkatkan set point suhu tubuh di hipotalamus. Hal ini menyebabkan peningkatan level prostaglandin E2 jaringan hipotalamus anterior dan ventrikel III, dengan konsentrasi tertinggi berada di sekitar organ vaskulosum lamina terminalis yang mempunyai jaringan kapiler meluas ke sekeliling pusat termoregulasi hipotalamus. Interaksi pirogen dengan endotel pembuluh darah akhirnya meningkatkan set point yang menyebabkan terjadinya demam. ${ }^{11-13}$

Teori patogenesis malaria dalam menyebabkan demam terus berkembang seiring perkembangan di bidang imunologi. Peran Toll Like Receptor-9 (TLR-9) dalam memerankan fungsi sel inang merupakan hal yang banyak diteliti saat ini. TLR berfungsi sebagai penerima tanda bahaya pertama. Seluruh jenis TLR bertanggung jawab dalam mengenali pola molekul dari patogen yang disebarkan oleh agen infeksius. Walaupun tidak bisa menetapkan suatu patogen sebagai mikroba tertentu, TLR bisa mengenalinya sebagai organisme asing. Setelah TLR mengenali pola antigen yang masuk, TLR mengaktifkan jalur NF$\mathrm{kB}$ yang menginduksi respon imun sel-sel dalam tubuh sehingga menyebabkan terjadinya pelepasan sitokin-sitokin proinflamasi, salah satunya TNF- $\alpha .^{14,15}$

\section{METODE PENELITIAN}

Penelitian deskriptif ini dilakukan selama 4 bulan, yaitu dari bulan Oktober 2013 sampai Januari 2014, di Laboratorium Biomolekuler Parasitologi Fakultas Kedokteran, Universitas Sam Ratulangi Manado. Dengan menggunakan simple 
random sampling diperoleh 40 sampel. Sampel diambil dari pasien anak di RSUP Prof. Dr. R. D. Kandou Malalayang dan RS Noongan dengan kriteria inklusi anak positif malaria pada pemeriksaan darah dan memiliki gejala klinis demam..

Pasien dengan pemeriksaan hapusan darah tepi dinyatakan positif malaria diukur suhu tubuhnya, kemudian sampel darah diambil melalui pembuluh darah vena. Kadar TNF- $\alpha$ serum diukur dengan menggunakan metode ELISA. Kadar TNF$\alpha$ dikatakan rendah bila $<100 \mathrm{pg} / \mathrm{ml}$; sedang $100-500 \mathrm{pg} / \mathrm{ml}$; dan tinggi $>500 \mathrm{pg} / \mathrm{ml}^{16}$

\section{HASIL PENELITIAN}

Gambaran tingkatan dan frekuensi demam pada 40 pasien yang dijadikan sampel memperlihatkan variasi antara 38,2$39,9{ }^{\circ} \mathrm{C}$, dengan suhu terbanyak $38,4{ }^{\circ} \mathrm{C}$ dan $39,1^{\circ} \mathrm{C}$ (Tabel 1).

Tabel 1. Tabel frekuensi suhu tubuh penderita malaria

\begin{tabular}{ccc}
\hline Suhu tubuh $\left({ }^{\mathbf{}} \mathbf{C}\right)$ & $\mathbf{n}$ & $\mathbf{\%}$ \\
\hline$\leq 38,5$ & 12 & 30 \\
$38,6-39,0$ & 11 & 27,5 \\
$39,1-39,5$ & 13 & $\mathbf{3 2 , 5}$ \\
$\geq 39,6$ & 4 & 10 \\
\hline
\end{tabular}

Dari seluruh sampel dapat dilihat adanya tingkatan demam dan kadar TNF- $\alpha$ yang bervariasi. Kadar TNF- $\alpha$ serum hanya dijumpai dari kadar rendah sampai sedang, dengan terbanyak pada kategori sedang (Tabel 2).

Tabel 2. Tabel frekuensi kadar serum TNF- $\alpha$

\begin{tabular}{cccc}
\hline $\begin{array}{c}\text { Kadar TNF- } \alpha \\
\text { (pg/ml) }\end{array}$ & Kategori & $\mathbf{n}$ & $\mathbf{\%}$ \\
\hline$<100$ & Rendah & 4 & 10 \\
$100-500$ & Sedang & 36 & 90 \\
$>500$ & Tinggi & - & - \\
\hline
\end{tabular}

Kadar TNF- $\alpha$ yang terendah pada sampel $75 \mathrm{pg} / \mathrm{ml}$ dan yang tertinggi 305 $\mathrm{pg} / \mathrm{ml}$. Dari hasil perhitungan, nilai ratarata suhu tubuh dari 40 sampel berada pada $38,9{ }^{\circ} \mathrm{C}$ dengan kadar serum TNF- $\alpha$ 155,7 $\mathrm{pg} / \mathrm{ml}$ (Tabel 3).

Tabel 3. Tabel hasil perhitungan mean dan median

\begin{tabular}{ccc}
\hline & Suhu tubuh & $\begin{array}{c}\text { Kadar serum } \\
\text { TNF- } \boldsymbol{\alpha}\end{array}$ \\
\hline $\mathrm{N}$ & 40 & 40 \\
Mean & 38,903 & 155,75 \\
Median & 38,85 & 142,5 \\
\hline
\end{tabular}

\section{BAHASAN}

Berdasarkan hasil penelitian yang telah dipaparkan, di temukan bahwa secara rata-rata peningkatan suhu tubuh diikuti dengan peningkatan kadar TNF- $\alpha$. Hal ini mendukung teori yang membahas efek TNF- $\alpha$ dapat menginduksi terjadinya demam. Dikatakan bahwa demam dapat terjadi oleh adanya induksi antigen yang dihasilkan parasit sehingga menghasilkan TNF- $\alpha$ yang selanjutnya menginduksi pelepasan prostaglandin yang menyebabkan terjadinya demam. ${ }^{11-13}$

Hasil penelitian ini serupa dengan penelitian Othoro et al (1999) ${ }^{17}$ pada anakanak di Western Kenya yaitu kadar TNF- $\alpha$ meningkat pada pasien positif malaria dan memiliki gejala klinis. Walaupun demikian, terdapat pasien dengan kadar TNF- $\alpha$ yang cukup tinggi tetapi mempunyai suhu tubuh yang tidak terlalu tinggi. Hal ini sesuai dengan teori mengenai imunitas yang terbentuk pada pasien yang tinggal di lingkungan endemis, seperti anti parasitic imunity dan anti disease imunity. ${ }^{18}$

Keberadaan TLR juga berpengaruh pada keadaan ini. Seperti yang sudah di jelaskan sebelumnya, saat TLR mengenali antigen yang masuk dan memberikan tanda bahaya pada tubuh, terjadi suatu mekanisme adaptasi oleh sel inang. Hal ini akan memberikan efek pada mekanisme selanjutnya yaitu pelepasan sitokin dan 
pengaruhnya sehingga memberikan suatu gejala klinik. $^{14,15}$

TNF- $\alpha$ dapat memiliki efek yang berbeda, tergantung dari kadarnya di dalam tubuh. Pada suatu inflamasi ringan, biasanya ditemukan kadar TNF- $\alpha$ rendah, tetapi kadar TNF- $\alpha$ sedang dapat memengaruhi pelepasan prostaglandin yang selanjutnya menyebabkan terjadinya demam, yang sesuai dengan hasil penelitian ini. Berbeda halnya dengan kadar TNF- $\alpha$ tinggi yang dapat menyebabkan terjadinya syok septik, terhambatnya kontraktilitas miokard dan otot polos pembuluh darah, dan gangguan metabolik berat. Oleh sebab itu, kadar TNF- $\alpha$ yang tinggi sering dihubungkan dengan terjadinya malaria serebral. Penelitian yang dilakukan oleh sebuah universitas di Madrid menunjukkan bahwa kadar TNF- $\alpha$ pada pasien malaria serebral mengalami peningkatan hingga 10 kali lipat lebih tinggi dari orang normal. ${ }^{13,16}$

\section{SIMPULAN}

Dari hasil penelitian disimpulkan bahwa secara rata-rata kadar TNF- $\alpha$ meningkat pada penderita malaria yang mengalami demam.

\section{DAFTAR PUSTAKA}

1. Harijanto PN. Malaria. In: Sudoyo AW, Setiyohadi B, Alwi I, Simadibrata M, Setiati S, editors. Ilmu Penyakit Dalam. (Edisi Kelima). Jakarta: Interna Publishing, 2009; h.2813-8.

2. WHO. World malaria report 2011. [homepage on the Internet]. 2011 [cited 2013 Sep 20]. Available from: www.who.int/malaria/world_malaria_r eport_2011/en/

3. Dachian YP, Hadidjaja P. Malaria. In: Hadidjaja P, Margono SS, editors. Buku Ajar Parasitologi Kedokteran. [Edisi Keempat]. Jakarta: Balai Penerbit FKUI, 2008; p. 7-14.

4. Natadiastra D, Agoes R. Penyakit oleh sporozoa darah dan jaringan. Parasitologi Kedokteran: ditinjau dari organ tubuh yang diserang. Jakarta: Penerbit Buku Kedokteran EGC, 2009; p. 209-16.
5. CDC. Malaria [homepage on the Internet]. 2012 [cited 2013 Sep 20]. Available from: http://www.cdc.gov/malaria/ about/facts.html

6. WHO. Malaria and its Control in the WHO South-East Asia Region. [homepage on the Internet]. 2012 [cited 2013 Sep 20]. Available from: www.searo.who.int/ entity/malaria/topics/Malaria_factsheet WMD2012.pdf

7. Miller LH, Baruch DI, Marsh K, Doumbo OK. The Pathogenic Basis of Malaria [serial online]. 2002 [cited 2013 Sep 22]; 415:673-9. Available from: www.nature.com

8. Kakkilaya BS. Pathogenesis of malaria [homepage on the Internet]. 2011 [cited 2013 Sep 22]. Available from: http://www.malariasite.com/malaria/Ev olution.htm

9. Nugroho A. Patogenesis Malaria. In: Harijanto PN, Nugroho A, Gunawan CA, editors. Malaria: dari Molekuler ke Klinis (Edisi Kedua). Jakarta: Penerbit Buku Kedokteran EGC, 2012; h.38-50.

10. Leduc D, Woods S. Temperature measurement in paediatrics. Canadian Paediatric Society. [homepage on the Internet]. Nodate [cited 2014 Feb 24]. Available from: http://www.cps.ca/ documents/position/temperaturemeasurement

11. Susanti N. Efektifitas kompres dingin dan hangat pada penatalaksanaan demam. Sainstis. 2012;1(1):55-64.

12. Netea MG, Kullberg BJ, Van der Meer JWM. Circulating cytokines as mediators of fever. Oxford Journals. 2000;31(5):178-184.

13. Abbas AK, Lichtman AH. Cellular and Molecular Immunology (Edisi Kelima). China: Saunders Elsevier, 2005; h.252-3.

14. Christmas P. Toll like receptors: Sensors that detect infection. Nature Education. 2010;3(9):85.

15. Schumann RR. Malarial fever: Hemozoin is involved but Toll-Free. PNAS. 2007;104(6):1743-4.

16. Mozes T, Barath I, Gornicsar $K$. Deviations in circulating TNF- $\alpha$ levels and TNF- $\alpha$ production by mononuclear cells in healthy human populations. Mediators of inflammation [homepage on the Internet]. 2011 [cited 2014 Feb10]. Available from: 
http://www.hindawi.com/journals/mi/2 011/972609/

17. Othoro C, Lal A, Nahlen B, Koech D, Orago A, Udhayakumar V. A low interleukin-10 tumor necrosis factor- $\alpha$ ratio is associated with malaria anemia in children residing in a holoendemic malaria region in Western Kenya. The
Journal of Infectious Diseases. 1999;179:279-82.

18. Nugroho A, Harijanto PN, Datau EA. Imunologi pada malaria. In: Harijanto PN, editor. Malaria: Epidemiologi, Patogenesis, Manifestasi Klinis dan Penanganan. Jakarta: Penerbit Buku Kedokteran EGC, 2000; p. 144-7. 